\title{
Effect of Short Steel Fibre Reinforcement on Laterized Concrete Columns
}

\author{
Efe Ewaen Ikponmwosa (Corresponding author) \\ Faculty of Engineering, University of Lagos \\ Akoka, Yaba, Lagos, Nigeria
}

Tel: 234-80-5489-7732 E-mail: efe_ewaen@yahoo.com

Musbau Ajibade Salau

Faculty of Engineering, University of Lagos

Akoka, Yaba, Lagos, Nigeria

Tel: 234-80-3330-3420 E-mail: ajibsalau@yahoo.co.uk

The research is financed by University of Lagos

\begin{abstract}
This paper reports on experimental investigation conducted to determine the effect of short randomly oriented and discontinuous steel fibres on the structural behaviour of laterized concrete columns. Thirty fibre reinforced concrete columns of $150 \times 150 \mathrm{~mm}$ cross-sectional area and $1200 \mathrm{~mm}$ in height and sixty number $150 \times 150 \times$ $150 \mathrm{~mm}$ cubes were cast and tested. Fifteen fibre reinforced concrete columns were provided with $8 \mathrm{~mm}$ mild steel links at $300 \mathrm{~mm}$ spacing while the remaining fifteen (15) specimens of the fibre reinforced concrete columns were not provided with links except at the top and bottom of the bars to hold the longitudinal reinforcements in position. The mix proportion for this investigation is 2:3:6 (cement: Laterite/sand: Granite) with 0.65 water/cement ratio. The specimens were cured in water at different ages up to 28 days at temperature of $21^{\circ} \pm 1^{\circ} \mathrm{C}$. The steel fibre was varied from $0 \%$ to $2 \%$ at $0.5 \%$ interval.

The first crack load and ultimate column strength increases with increasing fibre proportion up to an optimum fibre content of $1.5 \%$ of the volume of laterized concrete. There is approximately linear relationship between the ultimate strength and the percentage of fibres in the laterized concrete up to this optimum level. Results also indicate that an addition of $1 \%$ fibre by volume of concrete can be an effective replacement for $8 \mathrm{~mm}$ non-shear links in laterized concrete columns. It was observed that there was no appreciable effect of additional steel links on loading when fibres are present in the mix, showing that fibre reinforced laterized concrete short columns may be used without additional steel links in provision of minor structures, as well as low rise buildings, where nominal shear reinforcement is needed.
\end{abstract}

Keywords: Steel fibre, Laterized concrete, Strength, Deflection, Crack pattern

\section{Introduction}

Laterized concrete is concrete in which the fine aggregate has been partially or wholly replaced with lateritic soils in its natural form. Lateritic soils are readily available in Nigeria at building construction sites. They are easy to procure and do not require washing before use because they contain little or no organic material that can harmfully and chemically react with cement during hydration of cement in concrete. Steel is one of the most widely used and probably the most expensive of all reinforcing construction materials. Its high cost has however become a challenge in construction industry. The tensile strength of concrete can also be improved not only by use of steel reinforcement but also by continuously aligned fibres such as carbons, plastic, timber, etc. Fibre reinforced concrete [FRC] is defined as concrete made of hydraulic cement, fines, coarse aggregate and continuously aligned or randomly oriented short and discontinuous fibres.

Akin and Kara (Akin, S. K. and Kara, N. 2006) reported on the use of hooked steel fibres in place of stirrups in beam column connections subjected to cyclic loading. The results of the study carried out on five (5) beam-column connections revealed that hooked steel fibres, added to the concrete instead of the stirrups made the connections to be more ductile, hence, improving the load bearing, deflection and energy absorption capacities of the tested connections. Shannag et al (Shannag, M. J., Abu-Dyya, N. and Abu-farsakh, G. 2005) 
investigated the response of high performance fibre reinforced concrete beam-column joints to cyclic lateral loading and reported that steel fibre reinforced concrete specimens exhibited 3 times higher load bearing capacity level, 20 times larger energy dissipation level and 2 times slower stiffness degradation when compared to the control specimens. Hadi (Hadi, M. N. S. 2009) conducted studies on the effects of adding steel fibres to high-strength reinforced concrete columns with particular attention paid to concrete cover of the columns. Seven circular reinforced concrete columns with varying fibre contents were tested with concentric axial loading. Obtained results showed that although only minor improvements were noticeable for a fibre content of $1.0 \%$, however, the addition of $1.5 \%$ and $2.0 \%$ steel fibre to the concrete mixes increased the load at which cover spalling took place. Results also showed that the columns containing both fibre high-strength concrete in the outer concrete and high-strength concrete in the core exhibited higher levels of ductility than the columns containing fibre high-strength concrete throughout the entire cross-section.

Neves and Fernandes de Almeida (Neves, Rui. D. and fernandes de Almeida, J. C. O. 2005) investigated the influence of matrix strength, fibre content and and diameter on the compressive behaviour of steel fibre reinforced concrete. Two types of concrete matrix $\left(35 \mathrm{~N} / \mathrm{mm}^{2}\right.$ and $\left.60 \mathrm{~N} / \mathrm{mm}^{2}\right)$ and three types of fibres $(0.35 \mathrm{~mm}$ and $0.38 \mathrm{~mm}, 30 \mathrm{~mm}$ long) were considered in the investigation. The volume of fibre in the concrete was varied up to $13 \%$. Their findings indicated that the inclusion of fibres in concrete enhances its toughness and strain at peak stress, but slightly reduce the Young's modulus. Also, Duzgun et al (Duzgun, O. A., Gul, R and Aydin, A. C. 2005) presented the results of their study of the effects of steel fibres on the mechanical properties of pumice aggregate concretes. The volume proportion of pumice aggregate in the concrete was varied at $25 \%$ interval. Results of the study showed that the increasing pumice aggregate ratio decreased the unit weight and the mechanical properties of the concretes. Results further revealed that by the inclusion of steel fibre and the increase in ratio of same in the unit weight of concrete, compressive, splitting, tensile and flexural strengths of the concretes increased by $8.5,21.1,61.2$ and $120.2 \%$ respectively when compared to specimens without fibres. They concluded that the moduli of elasticity and deformation capability were decreased with increase of pumice aggregate and steel fibre ratio in the concrete mixes.

Kovacs and Balazs (Kovacs, I. and Balazs, G. L. 2003) carried out study on 21nos 2.0m long fibre reinforced concrete beams with longitudinal bars. The test variables were amount and type of fibres, amount of stirrups and type of longitudinal reinforcement (prestressed and non-prestressed). Results showed that steels fibres do not only increase shear capacity of the beams but also provide substantial post-peak resistance and ductility in conventional reinforced beams and prestressed pre-tensioned concrete beams.

Udoeyo et al (Udoeyo, F. F; Iron, U. and Odim, O. O. 2006) experimentally investigated some characteristics of concrete containing laterite as partial or full replacement of sand aggregate. They opined in their results that concrete with up to $40 \%$ replacement level of sand with laterite could attain design strength of $20 \mathrm{~N} / \mathrm{mm}^{2}$. Hence, they concluded that it is possible to use laterite as replacement for sand in concrete up to $40 \%$ replacement level.

Oluwaseyi (Oluwaseyi, 'Lanre, 2007) studied the influence of weather on the performance of laterized concrete. The study examined the weathering characteristics of laterized concrete with laterite-granite fine ratio as a factor. The simulation of weathering condition (wet \& dry) was carried out by conditioning laterized concrete cubes to varying temperature and alternate wetting and drying. The results of the investigation showed that generally, the compressive strength of laterized concrete with laterite-granite fine ratio variation decreases when subjected to alternate wetting and drying. However, he concluded that laterized concrete with a laterite-granite fine ratio of between 40 and $60 \%$ conditioned to a temperature range of $75-125^{\circ} \mathrm{C}$ attained compressive strengths up to $22.52 \mathrm{~N} / \mathrm{mm}^{2}$.

Salau (Salau, M. A. 2003) reported the results of investigation on comparative study of long-term deformations of laterized and normal concretes short columns under sustained loading. The results show that there were not much variation between the creep deformations of laterized and normal concrete short columns. However, the laterized concrete specimens, either sealed or unsealed, showed more creep and shrinkage deformations when compared to corresponding normal concrete. Results of the investigation further revealed a consistent pattern of creep-time curve for laterized and normal concrete specimens. The shrinkage-time curves were observed to be consistent but different from the creep-time curves. The investigation concluded by recommending that $25 \%$ laterite content of fine aggregate could be used in concrete mixes for long-term resistance and usage in load bearing short column members.

Salau and Balogun (Salau, M.A and Balogun, L.A. 1990) investigated the shear resistance of laterized concrete beams without shear reinforcement. The results of their investigation showed that the ultimate shearing stress of laterized concrete increases with increase in the amount of longitudinal reinforcement and there being 
approximately linear variation between the shear strength and the percentage reinforcement. Further, the presence of laterite in concrete in the concrete improves its post-cracking ability, stiffness and superior crack control and serviceability condition due to high ductility. Greenough and Nehdi (Greenough, T. R. and Nehdi, M. I. 2008) studied the shear behaviour of fibre-reinforced self-consolidating concrete slender beams without stirrups with the view to determine the suitability of using fibres to satisfy minimum shear reinforcement requirements in beams. They observed that the short discrete fibres significantly improved the shear behaviour of reinforced self-consolidating concrete slender beams and beams with $1 \%$ steel fibre incorporated in concrete matrix could achieve up to $128 \%$ increase in shear capacity over that of the control specimen without fibre. The experimental results obtained indicate the possibility of using fibres as nominal shear reinforcement in beams.

Ikponmwosa and Falade (Efe Ikponmwosa and Funso Falade, 2006) reported on comparative study of the strength properties of unreinforced and fibre reinforced normal and laterized concretes. The results showed a consistent trend of increase in values of strength with age in the specimens. A proportion of $45 \%$ laterite content as replacement of sharp sand in concrete produced the highest compressive strength.

Several works have been carried out by various researchers on normal and laterized concretes without fibres as well as on the effects of randomly oriented short fibres on various normal concrete structural elements like beams; but not much work has been done on the influence of fibres on laterized concrete columns. This report presents findings on investigating the effects of short and randomly oriented, straight steel fibre on strength of short laterized concrete columns with a view of expanding the application of fibre reinforcement in laterized concrete elements.

\section{Experimental Procedure}

Preliminary investigations were carried out to determine the specific gravity and particle size classification of the constituent materials of the concrete. The specific gravity of granite and steel fibres were done by using pycnometer while those of laterite and sand were determined using the density bottle. The coarse aggregate, crushed granite was of $12 \mathrm{~mm}$ maximum diameter and density of $2690 \mathrm{~kg} / \mathrm{m}^{3}$ while the fine aggregate is composed of laterite and sand with density of 2630 and $2600 \mathrm{~kg} / \mathrm{m}^{3}$ respectively. The results of sieve analysis and grading curves of the aggregates are given Figure 1.

The concrete for this investigation is produced from cement, laterite and sand, granite mixed in the ratio of 2:3:6 with water/cement ratio of 0.65 . The ratio of laterite to sand was $1: 3$ (25\% laterite and $75 \%$ sand) in the fine aggregate. The percentage of the steel fibre was varied from $0 \%$ to $2 \%$ volume of the concrete at incremental rate of $0.5 \%$. The steel fibres used are very short and thin needle like pieces of metal of $20 \mathrm{~mm}$ average length, mean diameter of $0.275 \mathrm{~mm}$ and mean aspect ratio of 73 with average density of $7,820 \mathrm{~kg} / \mathrm{m}^{3}$. Ordinary Portland cement was used and its properties conform to British standard [13].

Two sets of 15 No. $150 \times 150 \times 1200 \mathrm{~mm}$ column specimens each were cast and tested. Both sets of the columns were reinforced with 4 No. $16 \mathrm{~mm}$ diameter high tensile bars. Only one set of the column specimens was reinforced with $8 \mathrm{~mm}$ mild steel links at $300 \mathrm{~mm}$ spacing while the other set was not provided with links except at the top and bottom of the bars, to hold the longitudinal reinforcement in position. For each set of test specimens corresponding to a specific value of fibre content in the reinforced laterized concrete, 3 No. column specimens and 3 No. cubes were tested.

The specimens were demoulded $24 \pm 0.5$ hours after casting and stored in a curing tank containing clean water for 28 days before testing. Cube strength was determined on a 1000kN Avery Denison Universal Testing Machine at a loading rate of $19.93 \mathrm{kN} / \mathrm{min}$. Typical arrangement of the column specimens during tests is shown in Figure 2.

\section{Results and Discussion}

\subsection{Density and Compressive Test of Fibre Reinforced Concrete}

Table 1 shows the values of density and compressive strength of laterized concrete with different percentages of fibre in the mixes.

The results show that the density of plain laterized concrete is $2490 \mathrm{~kg} / \mathrm{m}^{3}$. This is slightly greater than $2400 \mathrm{~kg} / \mathrm{m}^{3}$, a value generally accepted average for plain normal concrete. This difference is due to the density of laterite $\left(2650 \mathrm{~kg} / \mathrm{m}^{3}\right)$, being slightly higher than that of sand $\left(2600 \mathrm{~kg} / \mathrm{m}^{3}\right)$. This variation of density of fibre reinforced laterized concrete with fibre contents is shown in Figure 3. The density of the fibre reinforced laterized concrete increases as the proportion of fibre in the concrete is increased. This is due to the density of steel fibre which is much higher than the density of the constituent materials of the laterized concrete. It was observed that the average density of the laterized concrete with fibre content in 
concrete mix of test specimens varied from $2527 \mathrm{~kg} / \mathrm{m}^{3}$ to $2628 \mathrm{~kg} / \mathrm{m}^{3}$ as the fibre content increased from $0.5 \%$ to $2.0 \%$ at $0.5 \%$ interval. This indicates an average increase of $1.37 \%$ in value of density of steel fibre reinforced laterized concrete as the fibre content increased from $0.0 \%$ to $2.0 \%$ at the indicated interval. Notwithstanding the increase in density of fibre reinforced laterized concrete as compared to normal concrete, the values are still in the region of normal weight concrete.

Furthermore, Table 1 and Figure 3 express numerically and graphically, respectively, the variation of compressive strength values of steel fibre-reinforced laterized as well as unreinforced normal concrete cubes relative to volume of fibre content in the concrete mix. The compressive strength of plain laterized specimens obtained at 28 days age was $23.65 \mathrm{~N} / \mathrm{mm}^{2}$. This value is however less than the cube strength of normal ordinary concrete (without laterite content) which is about $25.00 \mathrm{~N} / \mathrm{mm}^{2}$ (Ikponmwosa and Falade (Efe Ikponmwosa and Funso Falade, 2006)). The reduction in the cube strength of plain laterized concrete when compared to normal concrete could be attributed to the presence of very fine silty grains in the laterite which could have affected the quality of bonding between the cement and the aggregates.

Further, with increase in the volume content of fibre from $0.0 \%$ to $1.5 \%$ in the mixes, the cube strength increased. However, beyond this point, there was a reduction in the strength of the fibre laterized cubes. The cube strength corresponding to $1.5 \%$ fibre content was $29.35 \mathrm{~N} / \mathrm{mm}^{2}$ while that of $2 \%$ was $26.04 \mathrm{~N} / \mathrm{mm}^{2}$; indicating a reduction of $11.27 \%$. This reduction in strength could be attributed to poor bonding of concrete mix, arising from insufficient water to effect proper mixing of other constituent materials. At $2 \%$ fibre content, lumps of steel fibre coagulate in large quantity, resulting in balling effect, hence, inability to achieve a uniform distribution of fibre within concrete matrix at this level of fibre content. However, at $2 \%$ fibre content, the cube strength value was still higher than the strength of the unreinforced laterized concrete specimen by $2.39 \mathrm{~N} / \mathrm{mm}^{2}$, representing an increase in compressive strength of $10.1 \%$. Hence, it can be deduced that fibre improves the strength capacity of laterized concrete; however, optimum proportion of steel fibre to achieve maximum cube strength for fibre reinforced laterized concrete could be sustained at $1.5 \%$.

\subsection{Crack Pattern and Failure Mode}

Table 2 shows the response of fibre reinforced laterized concrete columns test specimens to axial loading as the fibre content increased from $0.0 \%$ to $2.0 \%$.

It is observed that in the test specimens without links and fibres in the concrete matrix, that is, unreinforced concrete, the appearance of cracks was not noticed before failure occurred. Failure was quite sudden and occurred at the points of application of axial load on test specimens.

In Figure 4, it can be seen that cracks initiated at the face of application of axial load and propagated to within one-third of the height of the column specimens. Micro cracks also appeared on all the faces of the columns. The cracks were wider at the points of application of loads, indicating the zone of maximum stress concentration. It is observed that the crack formation was similar for all tested specimens. Although in few cases, cracks occurred at both ends of test specimens, generally failure always occurred at one end. These cracks occur when the stress in the concrete exceeds its modulus of rupture. The percentage (\%) of crack load to collapse load with increase in fibre content (with or without links) is presented in Table 2.

\subsection{Effect of Fibres on Shear Resistance}

As the percentage of fibre content increased from $0.0 \%$ to $2.0 \%$ at $0.5 \%$ interval, the first crack load of the columns without links varied between 215.40 and $272.49 \mathrm{kN}$. This indicates a total increase in strength of $26.50 \%$. On average, for every 0.5 percent increase in fibre content, there was a corresponding $14.27 \mathrm{kN}$ increase in strength. This represents $6.63 \%$ improvement (increase) in strength for every $0.5 \%$ increase in fibre content. Likewise, for specimens with steel links, it was observed that first crack load varied between 219.21 and 286.60 $\mathrm{kN}$. This indicates an increase in strength of $67.41 \mathrm{kN}$; corresponding to $30.75 \%$ increase. This shows an increase in strength of $16.85 \mathrm{kN}(7.69 \%)$ for every $0.5 \%$ increase in fibre content in the concrete matrix. The increase in strength was more noticeable in all specimens up to $1.5 \%$ inclusion of fibre content. This same trend in strength increase relative to fibre content was also observed for the ultimate load of test specimens with and without steel links. However, for specimens with links, the increase in strength was $51.92 \mathrm{kN}(17.11 \%)$. This resulted in average of $12.48 \mathrm{kN}(4.28 \%)$ increase in strength. It was observed that the ultimate loads of test specimens reduced with inclusion of $2.0 \%$ fibre content. The value of ultimate load for $2 \%$ fibre content is not only lower than the value for $1.5 \%$ but also for all other proportions investigated, including the control specimens. This further confirms that $1.5 \%$ fibre could be considered as optimal fibre content for maximum strength of fibre reinforced laterized concrete columns. 
In all cases, it was observed that there was no appreciable effect of the steel links on the first crack loads and ultimate loads of specimens with fibres in the mixes. This indicates that steel fibres could serve as replacement for the steel links in laterized concrete columns.

Results of investigation presented in Table 2 further show that the inclusion of fibre in laterized concrete columns even without links, increased the values of crack loads and ultimate loads when compared with specimens with links only; but with $1.5 \%$ fibre content in column specimens without links, first crack load is $267.33 \mathrm{kN}$ while column specimens with links but without fibre content recorded $219.21 \mathrm{kN}$ at first crack load. The result showed an improvement of $21.95 \%$ with inclusion of fibre. This same trend is observed for the ultimate loads when test specimens with inclusion of $1.5 \%$ fibre but without links are compared with specimens with links but without fibres as this resulted in $19.14 \%$ increase.

From Table 2, it is noted that for first crack load, specimens with $0.5 \%$ fibre content but without links showed almost the same strength $(218.21 \mathrm{kN})$ when compared to specimens with $0 \%$ fibres but with steel links $(219.21$ $\mathrm{kN})$. Specimens with $1.0 \%$ fibre content but without links showed strength capacity of $347.74 \mathrm{kN}$ when compared to specimens with $0 \%$ fibres but with steel links which showed strength capacity of $303.50 \mathrm{kN}$. This improvement in capacities of the column specimens reinforced with fibres only over specimens reinforced with links only could be attributed to the ability of the fibres to provide appreciable nominal shear resistance in the concrete; the value which is considered more than that provided by links. This indicates that $1 \%$ fibre content could be a suitable replacement for $8 \mathrm{~mm}$ mild steel links (non-shear stirrups) in laterized concrete columns.

\subsection{Deflection Behaviour}

The horizontal deflection of mid-span of column specimens are observed on the dial gauges, positioned as indicated in Figure 2. Figures 5 and 6 show the load-deflection behaviour of fibre-reinforced laterized concrete columns with and without steel links irrespectively.

For all the columns without steel links, the range of central deflection is between 0.0 and $1.054 \mathrm{~mm}$, while for all columns with steel links, the range of deflection is between 0.064 and $0.880 \mathrm{~mm}$, depending on the percentage of fibre reinforcement. The maximum central deflection value $(1.054 \mathrm{~mm})$ was observed in column specimens with $1.5 \%$ fibre content in laterized concrete mix. In specimens without steel links, no definite trend in deflection pattern was observed. This could be attributed to the random dispersion of fibres in the concrete matrix. However, the values of deflections are in general, negligibly small; the maximum central deflection being $1.054 \mathrm{~mm}$. This is also an indication that failure of tested column specimens was not due to buckling. Unlike in the test specimens without steel links, Figure 6 shows that the deflection of columns with links tends to have a definite pattern.

Generally, in test specimens with fibre reinforcement only, for each load case and at pre-determined value of loading, as fibre content increased from $0 \%$ to $1 \%$, central deflection also increased in all test specimens. This suggests that fibre reinforcement in laterized concrete columns helps to improve the ductility of the specimen, despite the contribution of the laterite. In test specimens with links, generally, as the load increased on all test specimens, the rate of increase of deflection reduced. This shows that the steel links (stirrups) considerably helps in curtailing the buckling effect of loading on the column specimens, compared to fibres.

\section{Conclusion and Recommendations}

In many developing countries, such as Nigeria, where steel is not only expensive but is also difficult to obtain, the use of alternative reinforcing materials such as steel fibre and laterite may be ideal for non-critical structural members. The results of the experiments carried out on steel fibre reinforced laterized concrete columns show that:

The density and cube strength of fibre reinforced laterized concrete increases as the fibre content of the concrete is increased. $1.5 \%$ fibre content by volume is considered as optimum value of fibre in laterized concrete.

Cracks in the test specimens initiated at the face of application of axial load and propagated to within one-third of the height of the column specimens. Although micro cracks also appeared on all the faces of the columns, the cracks were wider at the points of application of loads, indicating the zone of maximum stress concentration. Cracks formation was similar for all tested specimens; although in few cases, they occurred at both ends of test specimens. The average load, at which the first crack occurred, increased as the percentage fibre content is increased from $0 \%$ to $1.5 \%$ for all test cases.

For non-critical construction, the inclusion of $1 \%$ fibre by volume of concrete can effectively be used as replacement for normal shear reinforcement in laterized concrete columns. 
The ductility of fibre reinforced laterized concrete increases as the percentage of fibre content is increased and the ductility reaches its maximum at about $1 \%$ fibre content. Samples with $0.0 \%$ fibre, showed little or no deflection capacity.

The first crack load and ultimate column strength increases with increasing fibre proportion up to an optimum fibre content of $1.5 \%$ of the volume of laterized concrete. There is approximately linear relationship between the ultimate strength and the percentage of fibres in the laterized concrete up to this optimum level. Results also indicate that an addition of $1 \%$ fibre by volume of concrete can be an effective replacement for $8 \mathrm{~mm}$ non-shear links in laterized concrete columns. It was observed that there was no appreciable effect of additional steel links on loading when fibres are present in the mix, showing that fibre reinforced laterized concrete short columns may be used without additional steel links in provision of minor structures, as well as low rise buildings, where nominal shear reinforcement is needed.

\section{References}

Akin, S. K. \& Kara, N. (2006). Use of Hooked Steel Fibres Instead of Stirrups in Beam-Column Connections. $J$. Fac. Eng. \& Arch., Selcuk Univ., v.21, n.1-2, pp.119-126.

British Standard 12. (1996). Specification for Portland Cement. British Standards Institution, London.

Duzgun, O. A., Gul, R \& Aydin, A. C. (2005). Science Direct - Effect of Steel Fibres on the mechanical properties Of Natural lightweight Aggregate Concrete. Materials Letters; Vol. 59 Issue 27, pp.3357-3363.

Greenough, T. R. \& Nehdi, M. I. (2008). Shear Behaviour of Fibre-Reinforced Self-Consolidating Concrete Slender beams. ACI Materials Journal, Vol. 105 No. 5, pp.467-477.

Hadi, M. N. S. (2009). Reinforcing Concrete Columns with Steel Fibres. Asian Journal of Civil Engineering (Building and Housing), Vol. 10, No. 1, pp.79-95.

Ikponmwosa, E. \& Falade, F., (2006). A Study on the Properties of Fibre Reinforced Laterized Concretes. Journal of Raw Materials Research, Abuja, Nigeria, Vol.3, No.1 pp.46-55.

Kovacs, I. \& Balazs, G. L. (2003). Structural Behaviour of Steel Fibre Reinforced Concrete. Structural Concrete; Vol. 4 Issue 2, pp.57-63.

Neves, Rui. D. \& Fernandes De Almeida, J. C. O. (2005). Compressive Behaviour of Steel Fibre reinforced Concrete. Structural Concrete; Vol. 6, Issue 1, pp.1-8.

Oluwaseyi, 'Lanre. (2007). The Influence of Weather on the Performance of Laterized Concrete. Journal of Engineering and Applied Sciences. 2(1), pp129-135.

Salau, M. A. (2003). Long-term Deformations of Laterized Concretes Short Columns. Building and Environment, Vol. 38, Issue 3, pp.469-477.

Salau, M.A \& Balogun, L.A. (1990). Shear resistance of reinforced laterized concrete beams without shear reinforcement. Building and Environment, Vol. 25, Issue 1, pp.71-76.

Shannag, M. J., Abu-Dyya, N. \& Abu-farsakh, G. (2005). Lateral Load Response of High-Performance Fibre Reinforced Concrete Beam-Column Joints. Construction and Building Materials, Vol. 19, Issue 7, pp.500-508.

Udoeyo, F. F; Iron, U. \& Odim, O. O. (2006). Strength Performance of Laterized Concrete. Construction and Building Materials; Vol. 20, Issue 10, pp.1057-1062.

Table 1. Density and Compressive Strength of Laterized Concrete

\begin{tabular}{|c|c|c|c|c|}
\hline $\begin{array}{c}\text { Percentage of } \\
\text { Fibre }(\%)\end{array}$ & $\begin{array}{c}\text { Average Cube } \\
\text { Mass }(\mathrm{kg})\end{array}$ & $\begin{array}{c}\text { Average Cube } \\
\text { Density }\left(\mathrm{kg} / \mathrm{m}^{3}\right)\end{array}$ & $\begin{array}{c}\text { Average Crushing } \\
\text { Load of Cube }(\mathrm{kN})\end{array}$ & $\begin{array}{c}\text { Cube Strength } \\
\left(\mathrm{N} / \mathrm{mm}^{2}\right)\end{array}$ \\
\hline 0.0 & 8.40 & 2490.0 & 532.08 & 23.65 \\
\hline 0.5 & 8.53 & 2527.0 & 597.14 & 26.54 \\
\hline 1.0 & 8.63 & 2557.0 & 629.72 & 27.99 \\
\hline 1.5 & 8.70 & 2578.0 & 630.31 & 29.35 \\
\hline 2.0 & 8.87 & 2628.0 & 580.50 & 26.04 \\
\hline
\end{tabular}


Table 2. Response to axial loading by Fibre Reinforced Laterized Concrete Columns

\begin{tabular}{|c|c|c|c|c|c|c|c|c|}
\hline \multirow{2}{*}{$\begin{array}{l}\text { Percentage } \\
\text { of Fibre } \\
\text { Content in } \\
\text { Column } \\
(\%)\end{array}$} & \multicolumn{2}{|c|}{$\begin{array}{l}\text { First Crack Load, p } \\
\qquad(\mathrm{kN})\end{array}$} & \multicolumn{2}{|c|}{ Ultimate loads, $\mathrm{N}^{\mathrm{e}}(\mathrm{kN})$} & \multicolumn{2}{|c|}{$\begin{array}{c}\text { Load difference } \\
d=\left[N^{e}-p\right](k N)\end{array}$} & \multicolumn{2}{|c|}{$\begin{array}{c}\% \text { Load difference } \\
e=(d / p) x(100 / 1)\end{array}$} \\
\hline & $\begin{array}{c}\text { Specimen } \\
\text { without } \\
\text { links }\end{array}$ & $\begin{array}{l}\text { Specimen } \\
\text { with links }\end{array}$ & $\begin{array}{c}\text { Specimen } \\
\text { without } \\
\text { links }\end{array}$ & $\begin{array}{l}\text { Specimen } \\
\text { with links }\end{array}$ & $\begin{array}{c}\text { Specimen } \\
\text { without } \\
\text { links }\end{array}$ & $\begin{array}{l}\text { Specimen } \\
\text { with links }\end{array}$ & $\begin{array}{c}\text { Specimen } \\
\text { without } \\
\text { links }\end{array}$ & $\begin{array}{l}\text { Specimen } \\
\text { with links }\end{array}$ \\
\hline 0.0 & $215.40 *$ & 219.21 & $215.40^{*}$ & 303.50 & 0.0 & 86.29 & 0.0 & 39.36 \\
\hline 0.5 & 218.21 & 225.19 & 259.36 & 325.49 & 41.15 & 100.30 & 18.86 & 44.54 \\
\hline 1.0 & 249.80 & 256.57 & 347.74 & 349.04 & 97.97 & 92.47 & 39.21 & 36.04 \\
\hline 1.5 & 267.33 & 270.02 & 351.00 & 355.42 & 83.67 & 85.40 & 31.30 & 31.63 \\
\hline 2.0 & 272.49 & 286.60 & 292.49 & 309.60 & 20.00 & 23.00 & 7.34 & 8.03 \\
\hline
\end{tabular}

Note.: (*) - Cracks were not noticed before sudden failure.

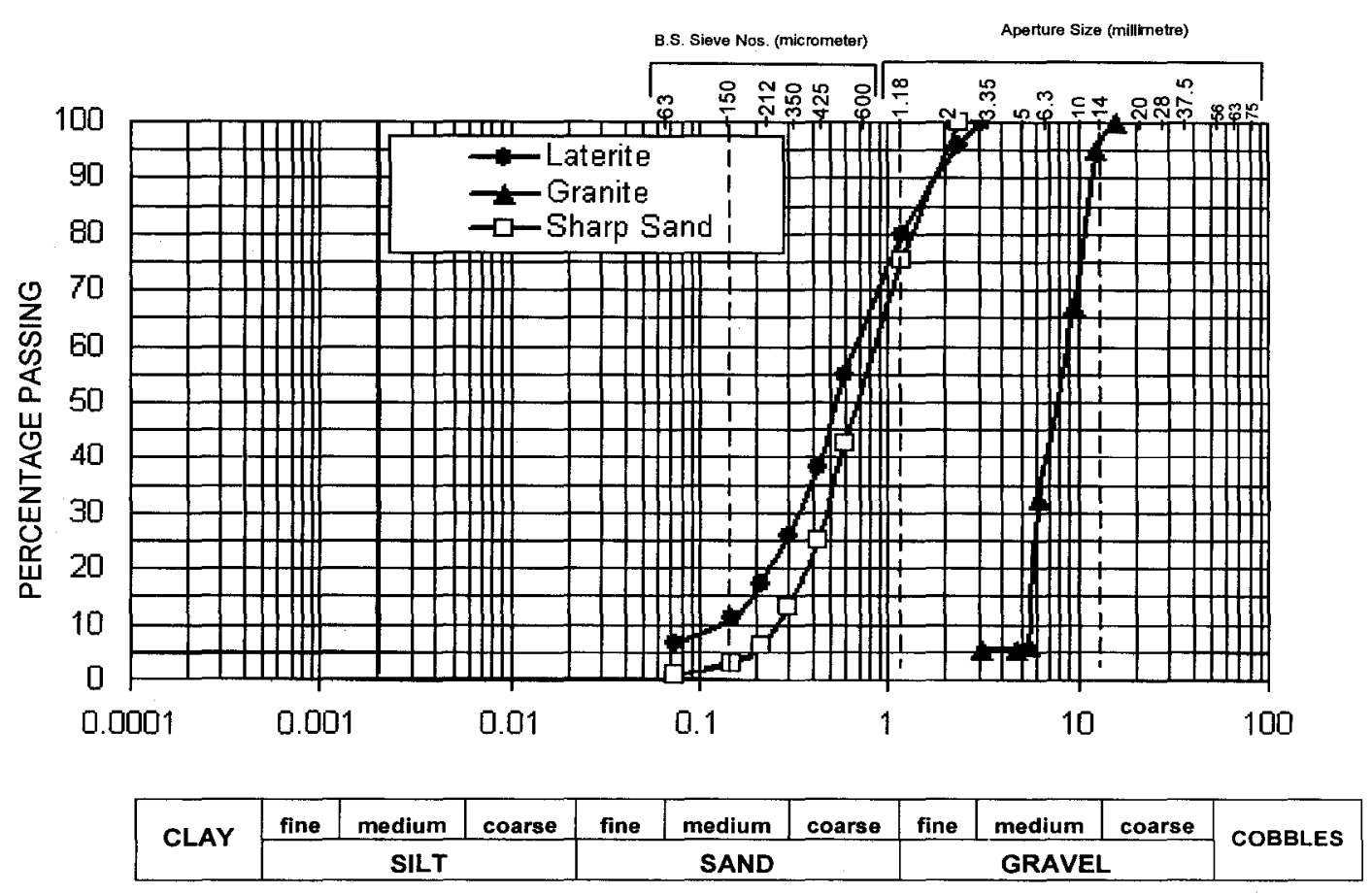

Figure 1. Particle Size Distribution Curves of Aggregates 


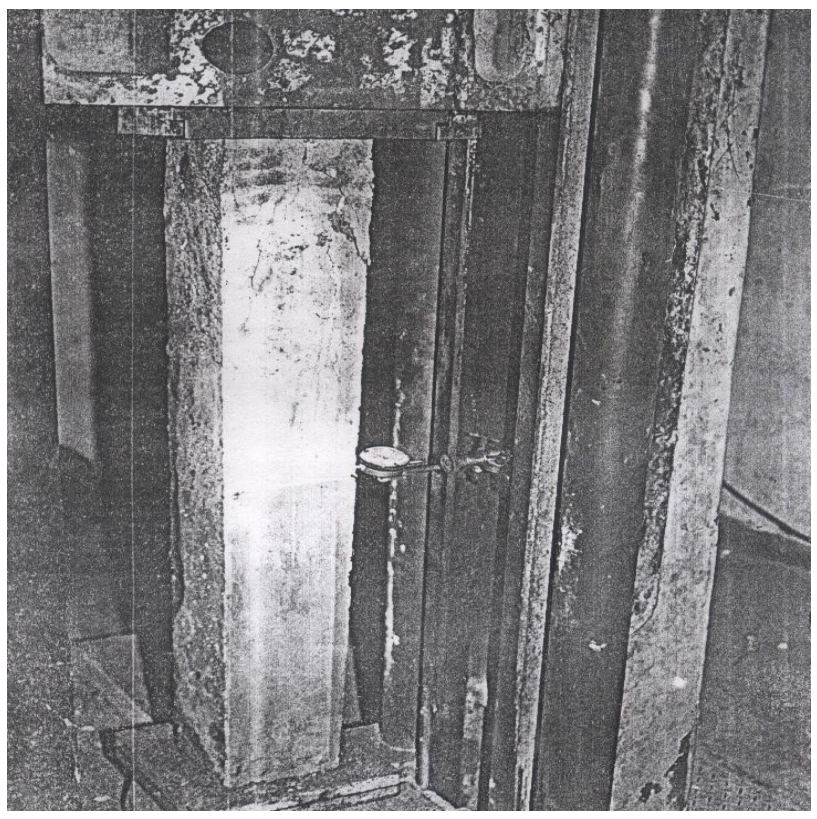

Figure 2. A Specimen on $1500 \mathrm{kN}$ Avery Denison Universal Testing Machine

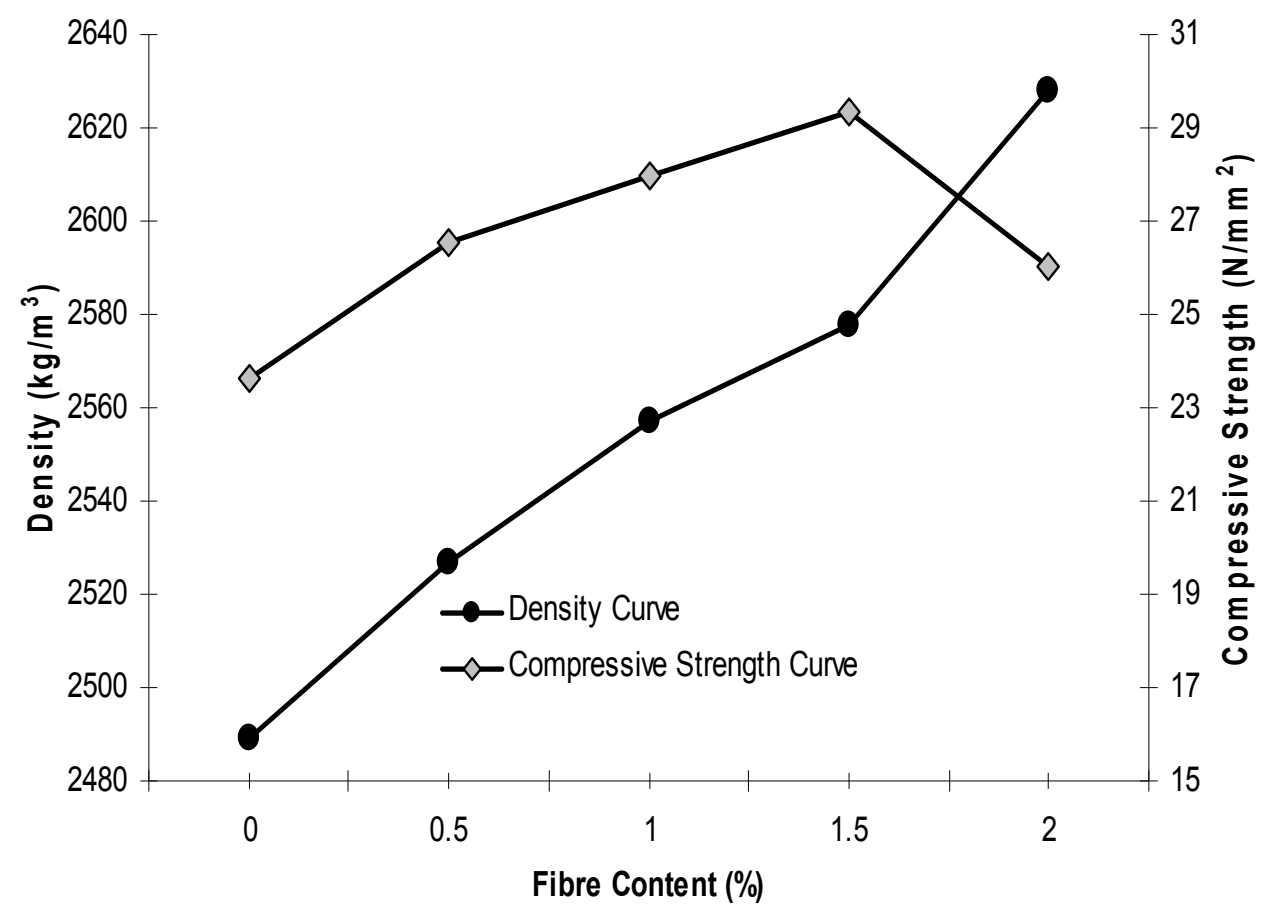

Figure 3. Variation of Density and cube Compressive Strength Ralative to $\%$ tage Fibre Content 


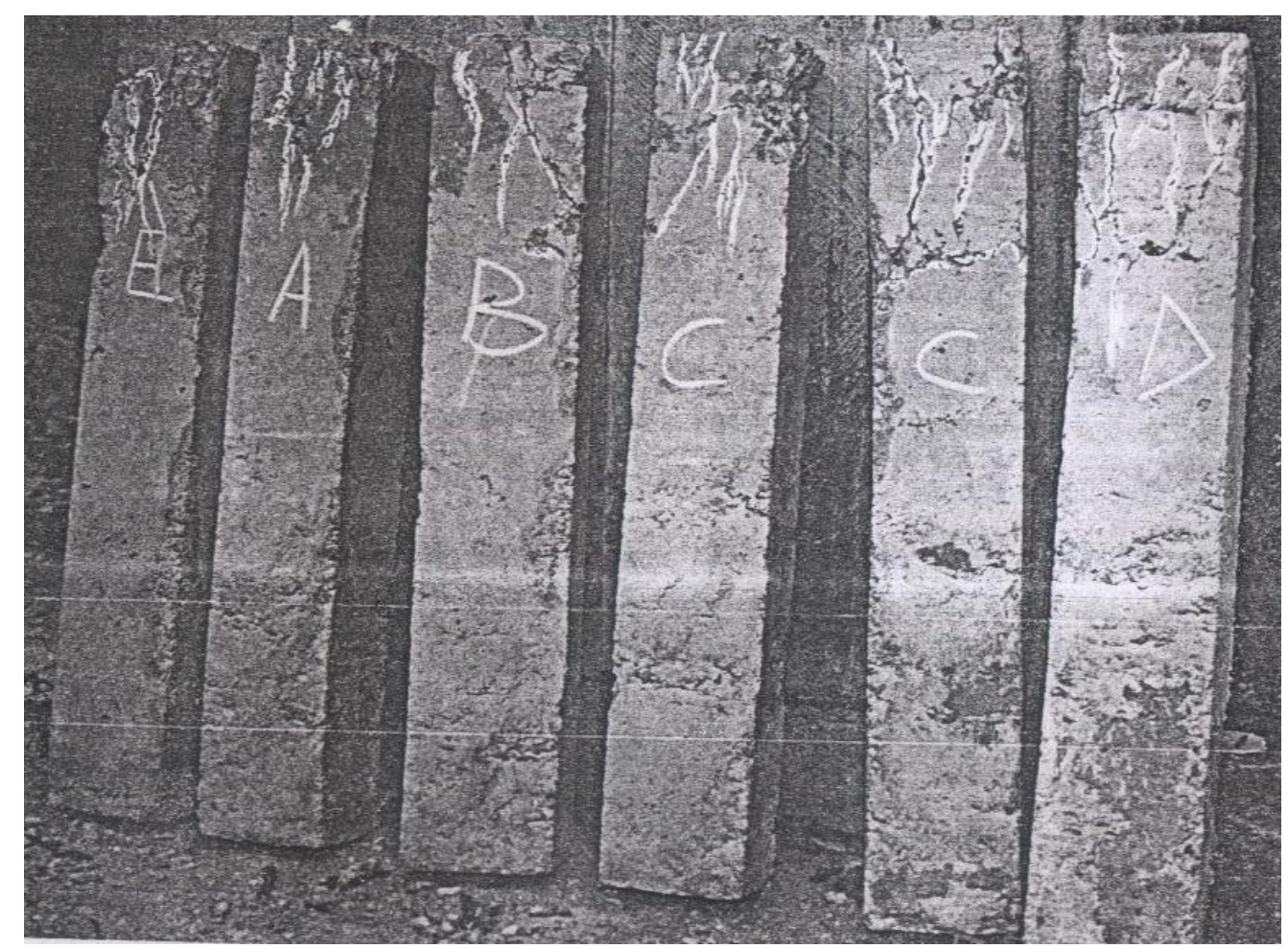

Figure 4. Typical Failure Mode of Column Specimens

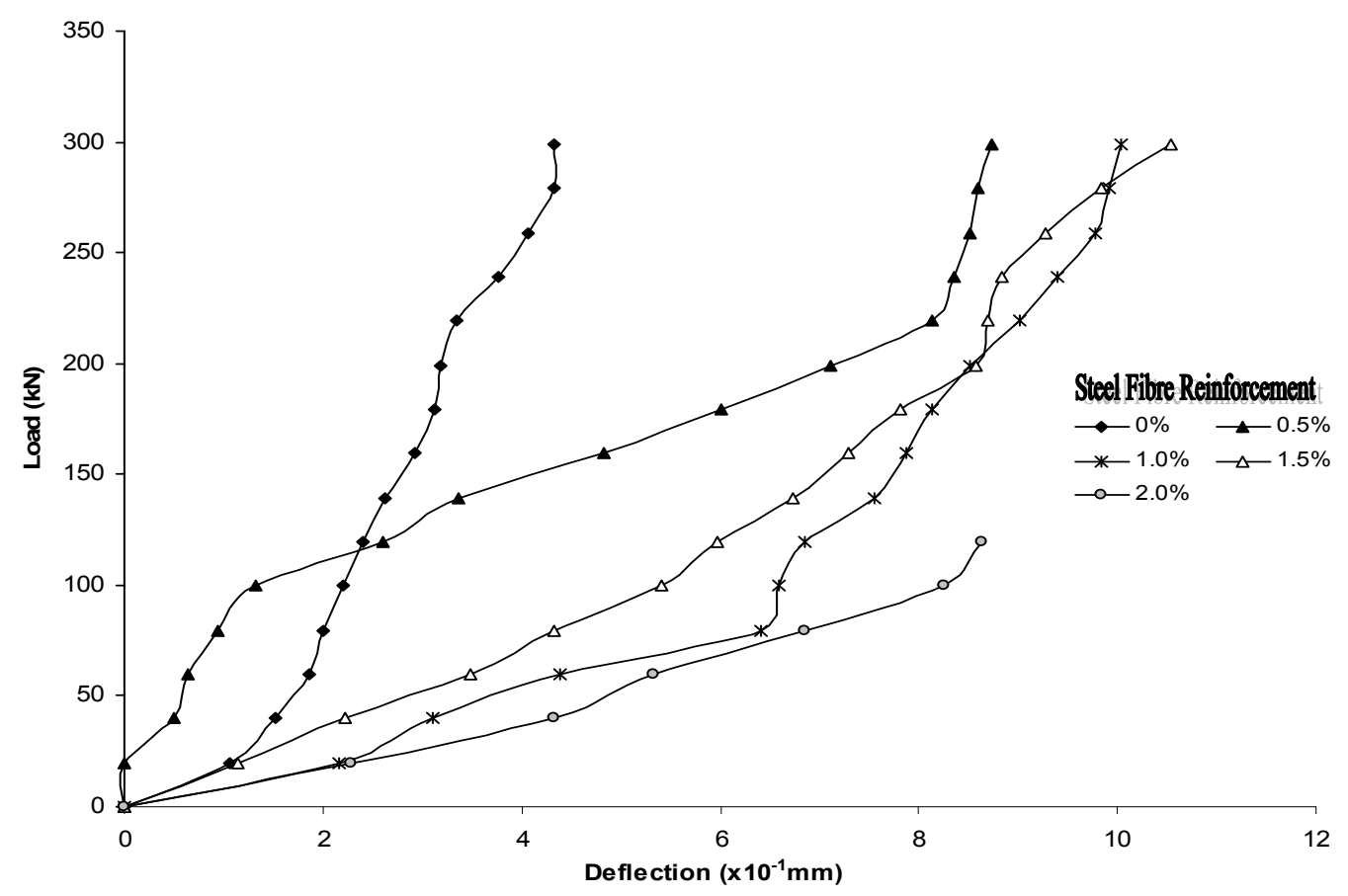

Fig. 5: Central Deflection of Steel Fibre Reinforced Laterized Concrete Columns (Specimens Without Links) 


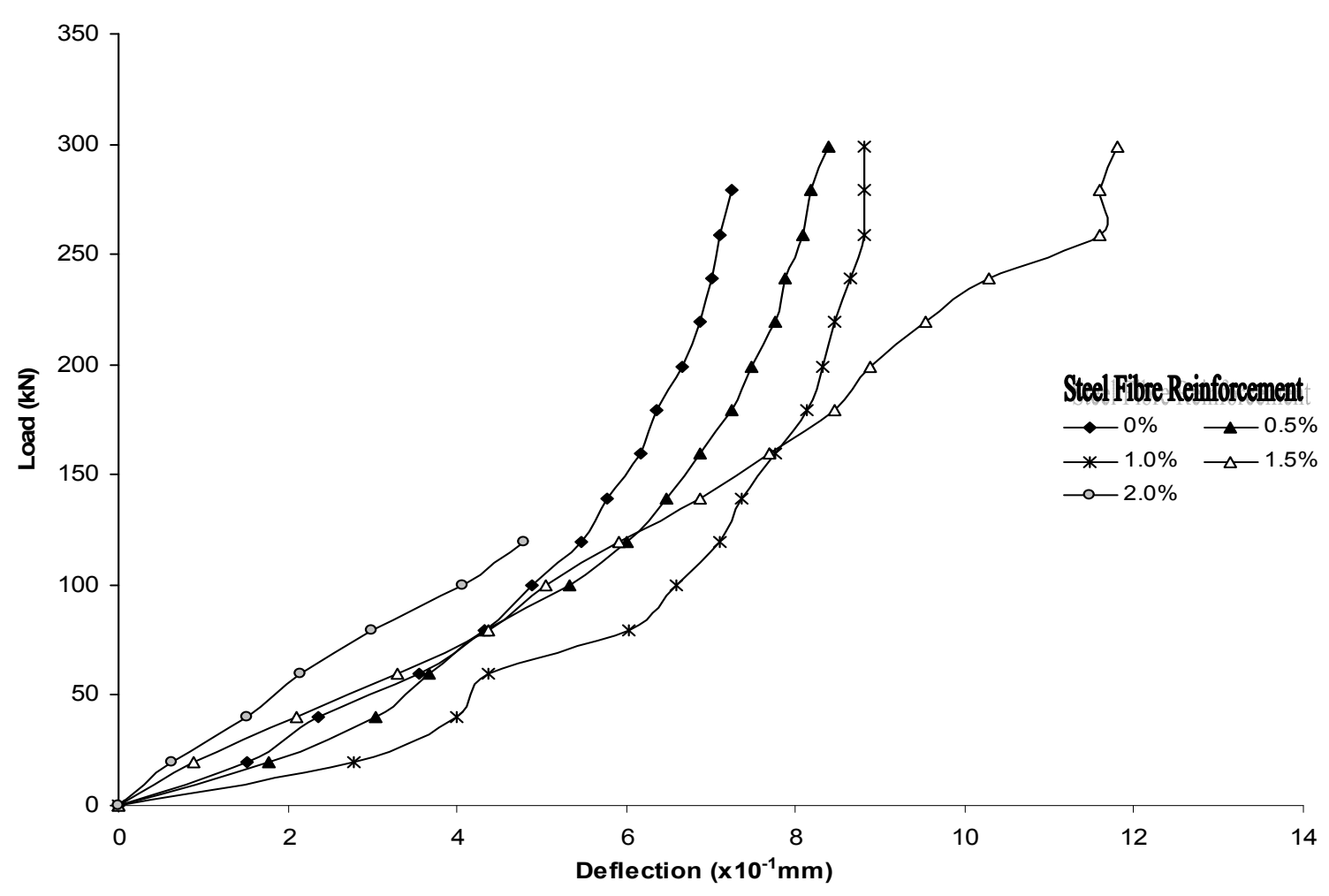

Fig. 6: Central Deflection of Steel Fibre Reinforced Laterized Concrete Columns (Specimens With Links) 